\title{
DAS ALTJÜDISCHE
}

\section{ZAUBERWESEN}

VON

\section{DR. LUDWIG BLAU,}

PROFESSOR AN DER LANDES-RABBINERSCHULE ZU BUDAPEST.

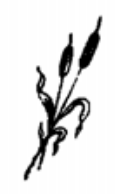

STRASSBURG i. E.

KARL J. TR ÜBNER 1 s98. 
